\title{
Modern Heritage, the Other, and the Anthropocene
}

\author{
Edward Denison
}

The Bartlett School of Architecture, University College London, London, United Kingdom

Email: e.denison@ucl.ac.uk

\begin{abstract}
The $20^{\text {th }}$ century was modernism's century; a comparatively fleeting moment in which the human race's transition to an urbanised species created an entirely new geological epoch: the Anthropocene. The existential challenge for our species in the $21^{\text {st }}$ century will be to transform the modern city into a site of truly sustainable human habitation. This challenge requires us to engage critically with the past in a way that serves the needs of the future, globally and permanently. The Historic Urban Landscapes (HUL) approach, together with the UN's Sustainable Development Goals and UN Habitat's New Urban Agenda, offers a framework for meeting this challenge and, critically, to change our relationship with both the past and the future.
\end{abstract}

KEYWORDS modernism, heritage, Anthropocene, multiple modernities, Historic Urban Landscapes (HUL), the other, UNESCO

Received October 24, 2018; accepted November 27, 2018.

\section{A Sense of Perspective}

At the dawn of the third millennium, we are living in an age of rapid and unprecedented change, the destabilising effects of which are felt not only in the daily lives of the 7.6 billion humans that now populate this planet, but also in the myriad systems that have sustained life on Earth for over four billion years. The speed, depth and scope of change might appear overwhelming, but if we fail to grasp its significance and respond proportionately, we face the threat of losing not merely our collective heritage but also the cultural and natural systems on which these essential assets depend.

The tipping point was the $20^{\text {th }}$ century-modernism's century-which bore witness to the first ever human-induced change on a planetary scale and laid the ground for the urbanisation of our species within the first decade of the $21^{\text {st }}$ century. Modernism's instrumental role in effecting this change, resonated with the clarion call of modernisation that rang out ever more loudly and widely across the globe after the Second World War. The modern city, planned and built to accommodate the proliferation of our species, exemplifies this process of change and has in turn assumed its place in the wider landscape of urban heritage with the comparatively recent global acceptance of modernism's contribution to humankind's collective heritage.
The $21^{\text {st }}$ century will, however, bear witness to humankind's success or failure to manage the consequences of this planetary change. For those engaged in the built environment professions broadly, or the heritage sector more specifically, the stakes could not be higher. Over the last hundred years, modernity has precipitated a more than quadrupling of the human population, the urbanisation of our species and the globalisation of human cultures. For the heritage industry, established in the $20^{\text {th }}$ century on principles from the $19^{\text {th }}$ century, the scale and pace of change in the $21^{\text {st }}$ century highlights the urgent need to devise new methods and approaches that move beyond the industry's Eurocentric foundations and begin to confront the planetary challenges that will decide our fate as a global species.

The experience of change is of course subjective. $\mathrm{Hu}$ man-induced climate change, for example, is a planetary phenomenon whose pace of change causes it to be refuted by many, despite overwhelming scientific evidence to the contrary. In contrast, the speed and shock of urban change, make it irrefutable, affecting our daily lives and impacting significantly on our perceptions of and responses to built heritage. As one resident of Shanghai lamented: 'Changes are going on continually all over the city. Day by day old buildings are disappearing and modern ones rising in their place. It is to be feared that many of the ancient landmarks 


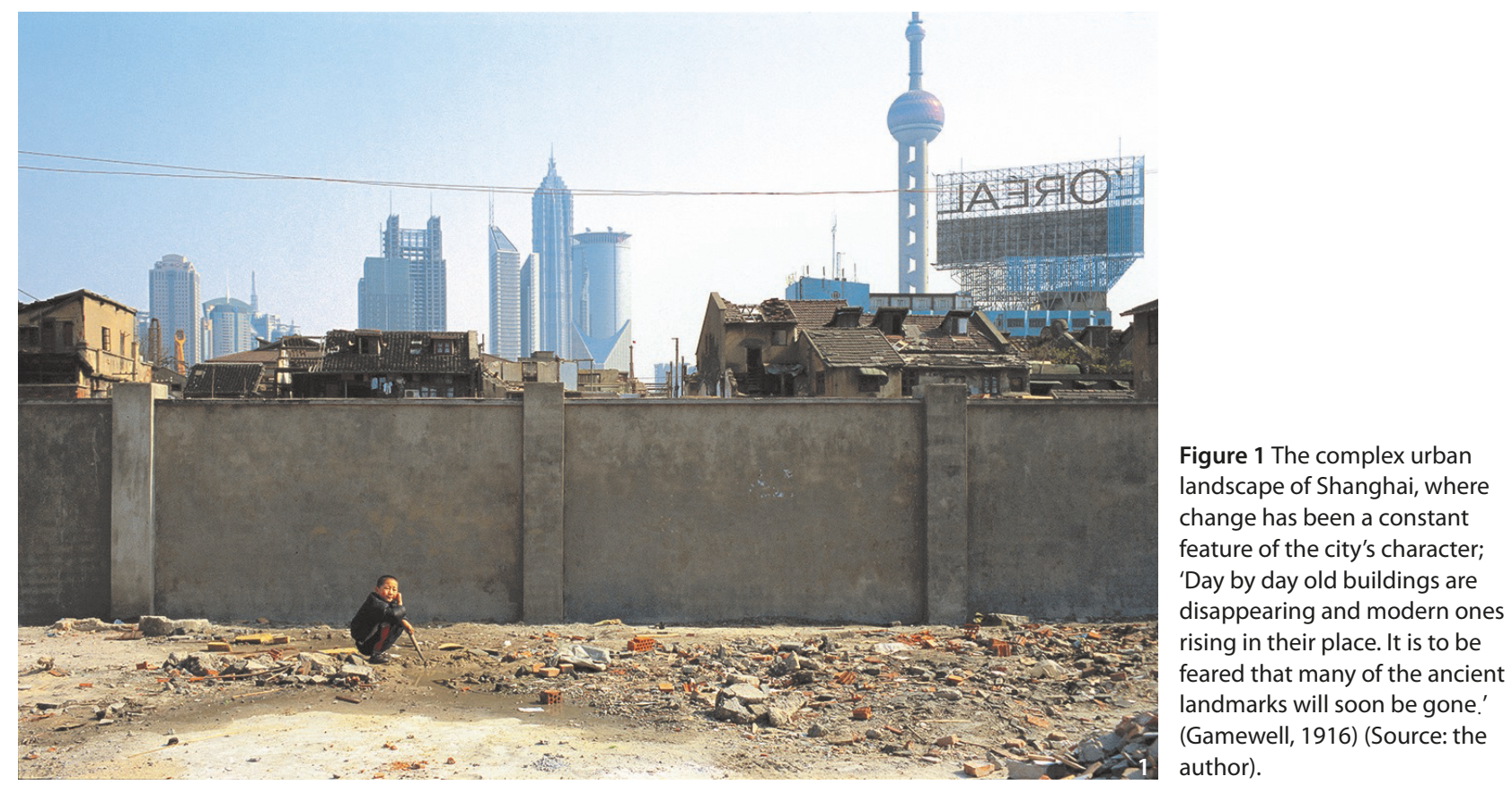

will soon be gone.' (Gamewell 1916) (Figure 1) As Shanghai, with its 24 million residents, has grown to comprise a quarter of the 100-million-strong Yangtze Delta Economic Zone, the city's built heritage has encountered dramatic change, yet these mournful words were penned not in the $21^{\text {st }}$ century, but rather a century ago, in 1916, when Shanghai was still under the control of a quasi-colonial cabal of foreign interests led by the British. Such examples prove the certainties that culture is constantly changing and change is constant.

However, the temporal dissonance between long- and short-term change has critical implications far beyond the heritage sector that we can no longer ignore as we embark on the new millennium. The consequences of human-induced change over the last century are beginning to reveal their profound and destabilising effect on the world. From climate change to the urbanisation of our species, the evidence of humankind's planetary impact in the modern era has precipitated an entirely new geological epoch: the Anthropocene. As the agreed nomenclature of this new epoch suggests, the principal characteristic of this departure from the Holocene, which lasted 12 thousand years, is an age defined by the human species and its collective bearing on the planet it has come to dominate.

This paper explores the modern heritage industry and the prevailing problems and the challenges it faces in the $21^{\text {st }}$ century, making a case in support of the need for new approaches to urban heritage that adequately and effectively respond to the challenges of this new geological age. With modern heritage as its principal subject and frame of reference and in keeping with the most progressive approaches to urban heritage, this paper advocates a planetary perspective and the need to adopt an inclusive, integrated and comprehensive approach to heritage in the Anthropocene.

\section{Architectural Heritage and the Other}

Since the signing of the Venice Charter in 1964 (ICOMOS 1964), the institutionalisation and phenomenal growth of the heritage industry has had a profound and positive impact on our understanding and handling of the world's heritage assets. However, more than half a century later, the founding principles, definitions and recommendations have had equally profound unintended consequences that future heritage professionals need to resolve. These can be seen as a reflection, perhaps inevitably, of the industry's Western (and predominantly male) origins and are evidenced most clearly in a phenomenon here described as 'othering' - where the voice of the 'other' is muted by a dominant master narrative.

The cultural and geographical foundations on which the international heritage industry was built are reflected in the title of the Venice Charter. Of the 23 signatories responsible for drafting the International Charter for the Conservation and Restoration of Monuments, 21 were male, 19 were European, three were American, and one was from North Africa (Tunisia). None were from Asia, Oceania or Sub-Saharan Africa. The inherent Eurocentricism of the modern heritage industry's founding fathers (literally) was 
further entrenched in the 1972 World Heritage Convention following UNESCO's Convention Concerning the Protection of the World Cultural and Natural Heritage held in the European capital of Paris in the same year.

The Eurocentricism that imbues $20^{\text {th }}$ century claims to internationalism was not confined to the embryonic heritage industry. In architecture, modernism's claims to a universal internationalism was firmly established by the seminal exhibition, Modern Architecture: International Exhibition, at New York's Museum of Modern Art in early 1932 and reinforced by the accompanying publications: an eponymous exhibition catalogue and The International Style by Henry-Russell Hitchcock and Philip Johnson (Hitchcock and Johnson 1997). The all-male exhibition committee selected works from an all-male cast of architects drawn exclusively from Europe and North America. Of the 70 sites that Hitchcock and Johnson included in their published survey, all except one were from Europe or the United States of America: an Electrical Laboratory (1929) in Japan designed by Yamada Mamoru for the Ministry of Public Works ${ }^{1}$. Although it made it into this exclusive Western club, this building in Osaka did not escape being wrongly attributed to Tokyo ${ }^{2}$. Just one photograph was used to illustrate Mamoru's design, compared with the 132 other plans and photographs of mostly European buildings that furnished the book and constructed the powerfully persuasive white-cube aesthetic of this new 'international' style.

It is important perhaps at this point to emphasise that this is not about seeking to undermine the significance of these celebrated works or their subjects, but to challenge their claims of universality or internationalism and to consider the consequences of the pre-eminence they have enjoyed for nearly a century. The narrative constructed around modernism and its urban and architectural production as a result of publications, exhibitions and subsequent uncritical and restricted professional and academic enquiry, has had a profound and constraining effect on the architectural and cultural historiography of the modern era. This problem is highlighted in the context of the art of the 'other' by the art historian, Professor Partha Mitter, who cites as an example the influential book Art Since 1900 (Foster et al. 2004): 'None of this would be problematic,' he argues, 'if the title of the book were, for instance, Western Avant-Garde Art since 1900 or Western Art since 1900.' (Mitter 2008) Claims to universality, consciously or otherwise, by European authors silences the voice of others, resulting not only in preventing the acknowledgement or narration of other histories, but also, importantly, undermining how we understand our own histories through a lack of comparison and failure to recognise interconnectedness. Such examples can be found throughout Western academia. In architecture, William Curtis's excellent and seminal book, Modern Architecture Since 1900 (Curtis 1982), while laudable in its attempt to provide a genuinely global outlook, makes no reference to China before 1949 and little mention of India or SubSaharan Africa, regions that collectively comprise over half the world's population and which experienced very significant encounters with modern architecture.

No single architectural image reflects this problem more succinctly than the 'Tree of Architecture' in the fifth edition of Sir Banister Fletcher's A History of Architecture (Fletcher 1905) (Figure 2) ${ }^{3}$. First published in 1896, it has since been among the most important, if not the most important, texts for many students of architecture and architectural history around the world. Growing straight and tall, the Tree of Architecture's robust trunk unambiguously represents the genealogy of the profession, rising up from the fertile sources of Greece and Rome through the Romanesque before blossoming into a thick canopy that blooms with the fruits of different styles of European building. Much of the rest of the world is represented by lesser fruit that hang singularly from the comparatively lean lower branches. Except for Egypt, the entire continent of Africa does not even feature-a landmass with more human genetic diversity than the rest of the world combined, yet no legitimate claim to architecture. This $19^{\text {th }}$-century image should be as shocking to architectural historians as the racist literary and graphic depictions of colonial subjects are to modern historians of literature and art, but it is not.

This may seem trivial or perhaps even an unfair revisionist interpretation of a well-intended illustrative model of architectural historiography drawn at the time the profession was finding its feet in the early $20^{\text {th }}$ century. However, significance here lies not in what was done by our forebears in their time, but in the impact their work has had on later generations, whose uncritical response (until comparatively recently) to foundational prejudices compounded rather than amended institutional bias.

Sir Banister Fletcher's seminal tome has been extensively revised through repeated attempts to keep it up to date, but as the $21^{\text {st }}$ century got underway it was decided the book needed a complete overhaul to make it fit for purpose in a global age. The initial structure of this proposed revision divided the last millennia into three temporally arbitrary periods within which the old 


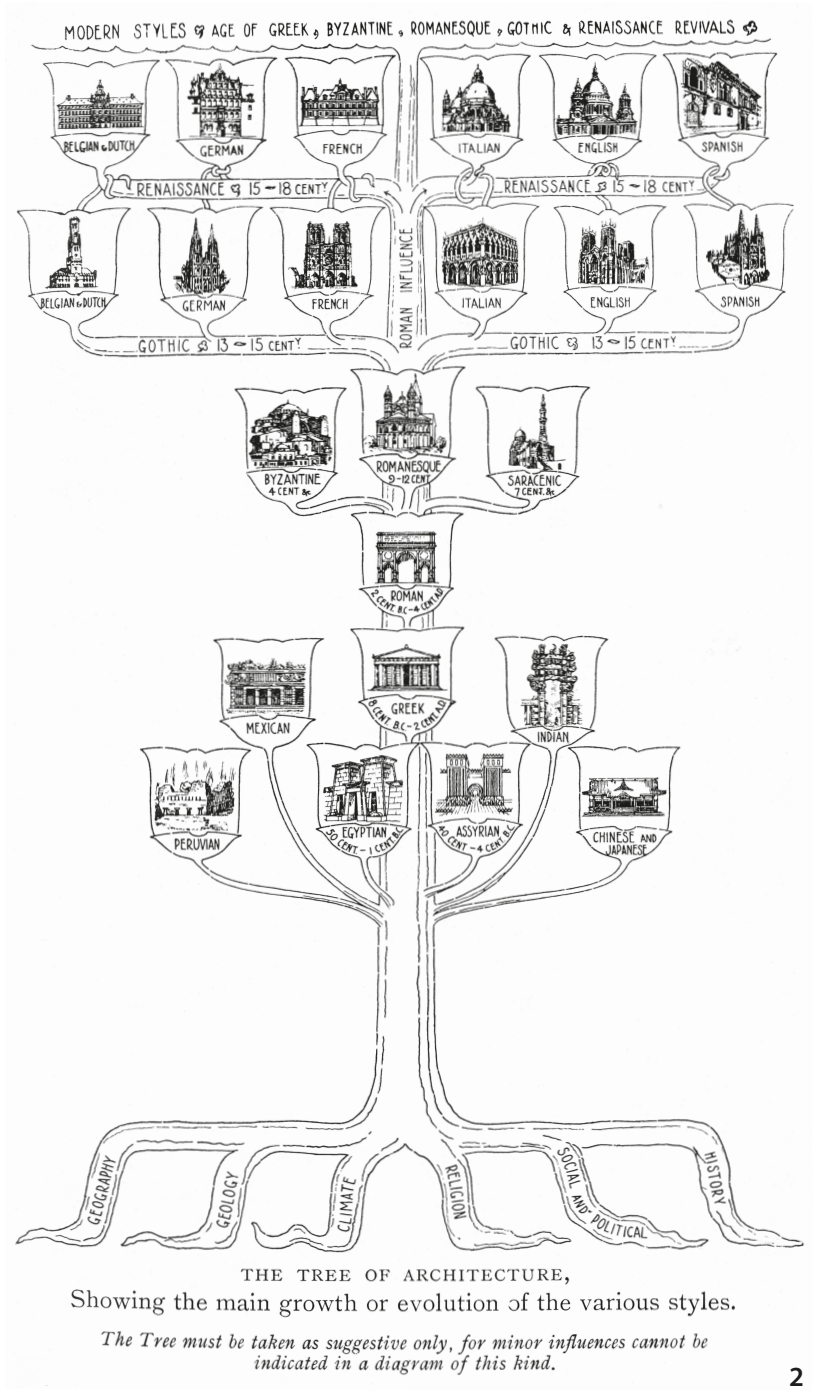

Figure 2 The 'Tree of Architecture', first published in 1905 in the fifth Edition of Sir Banister Fletcher's A History of Architecture (Source: RIBA).

stereotypes that were instilled by the founding author in the $19^{\text {th }}$ century prevailed. For example, in the chapter covering 1400-1830, Europe was allocated 81,000 words, while China was given 8,500 and the continent of Africa was given 5,000. The next chapter, 1830-1914, China and Africa fared little better, with 4,000 and 5,000 words each respectively compared with Europe's 44,000 words. In the modern era, from 1914-present, Africa again, by now a continent comprising 54 countries and 1.2 billion people, was given just 5,000 words, while Europe enjoyed over 10 times the space (52,500 words) in which to narrate its history. Only with the interventions of Professor Murray Fraser from the Bartlett School of Architecture, UCL, who was appointed editor later, have these early disparities been partially redressed.

Professor Fraser's interventions notwithstanding, if one's reaction to this might be to consider it a comparatively insignificant matter confined to the equally insignificant field of architectural history, it proves this paper's central thesis. The writing of history is a reflection of as much as it is a contribution to society and the latent cultural prejudice therein. The architectural history narrated by Banister Fletcher might have been aimed at architects and historians, but the underlying message reaches a far wider audience, some of whom are willing to spend tens of millions of dollars and exercise huge national resources in pursuit of its central doctrine-namely giving real cultural meaning and value to artefacts, buildings, monuments, ensembles and, increasingly, entire cities, based on assessments whose basis relies on the historical record, irrespective of whether or not this record is stuck on repeat. For proof, we need look no further than UNESCO's World Heritage List, which, since its inception in 1978, has unwittingly become a global inventory of cultural prejudice.

The World Heritage List's Eurocentricism has long been the cause of concern within and beyond the cultural sector, leading to the launch of various initiatives aimed at redressing the growing imbalance between not only the types of sites, but also their geographical distribution. Following a study conducted by ICOMOS from 1987 to 1993 that revealed 'Europe, historic towns and religious monuments, Christianity, historical periods and "elitist" architecture (in relation to vernacular) were all over-represented on the World Heritage List,' UNESCO initiated the Global Strategy in 1994 (UNESCO 2018a). However, despite these efforts a quarter of a century on, the List remains critically imbalanced.

For a site to be inscribed on the List, nominated sites must be deemed to possess 'outstanding value to humanity ... irrespective of the territory on which they are located' (UNESCO 2018b). If this were true, heritage professionals and the global public should be troubled by the fact that in 2018, Europe possesses exactly half of all UNESCO's cultural World Heritage Sites (422 of 845). The asymmetry with other continents is a grave concern and most starkly revealed in the African context. Italy (49) and Germany (42) possess more cultural sites than the 54 countries that comprise the entire continent of Africa (88). Or, to put it another way, Sub-Saharan Africa with its exceptional climatic, geological and ethnic range has just three more cultural sites than Italy. Much could be read into these facts, but what they starkly reveal is the consequence of decades of bias cumulatively constructed through research, policymaking, and the writing of rules, regulations and historical narratives that favour the author and discriminate others. This creates a self-fulfilling cycle that ingrains and 
instils profound and deep-rooted prejudices that prevent a fair representation of global history and culture, and undermine our ability to construct new knowledge.

The issue here is a question of power-a classic case of the victor's narrative. Modern architectural history, like the global heritage industry, is a product of the West, which enjoyed a pre-eminent position when these institutions were being established. This reality is what has motivated Guangyu Ren and me to research and write about subjects outside 'the West', such as the Eritrean capital of Asmara (which has since been inscribed on UNESCO's World Heritage List for its modernist architecture), architectural modernity in China, and Japanese imperialism in Manchuria. Following the publication of Ultra-Modernism: Architecture and Modernity in Manchuria (Denison and Ren 2017), I was asked to explain this in a piece for the RIBA Journal in which I attempted to summarise the over-arching position:

History is a record of power. The $20^{\text {th }}$ century-modernism's century-was dominated by 'the West'; its 'official' history bearing testimony to the west's dominance of 'others'. Modernist architectural history is a canon constructed by, for and of the West. This has major consequences for architectural encounters with modernity outside the West, which are routinely overlooked or possess an assumed inferiority; a postulation asserted through inauthenticity, belatedness, diluteness and remoteness, geographically, intellectually, and even racially (Denison 2017, 45).

\section{Multiple Modernities}

Much is now being done to redress the historical and historiographical asymmetries that have characterised architectural history since its inception as a formal academic discipline, along with its associated industries, including the heritage sector. This positive trend will only increase as the geo-political (and consequently intellectual) influence of the West recedes, revealing rich and fertile territories once concealed below the high-water mark of Western hegemony up to the late $20^{\text {th }}$ century. Different disciplines have responded to this new terrain in different ways and with varying degrees of enthusiasm over recent decades. The vanguard has been the social sciences, who have helped fashion this new landscape as much as they have profited from the opportunities it has presented. In the Preface to the 1998 Summer Edition of Daedalus the Journal of the American Academy of Arts and Sciences titled
'Early Modernities', the editor noted that 'It is a fact that Asia, like Africa and Latin America, figures less in major scholarly tomes than do either Europe or North America.' (Graubard 1998, vi) This seemingly obvious and innocuous statement of fact casts a spotlight on a fundamental problem in the arts, humanities and social sciences that, for architecture and heritage, remains as accurate now as it was a century ago.

One of the reasons why both modern architectural historiography and modern heritage have been framed largely by Western values and perspectives is that their foundation coincided with an era dominated by the prevailing and persuasive assumption that modernisation and Westernisation could be equated. Two years after the publication of 'Early Modernities', the 2000 Winter Edition of Daedalus was titled 'Multiple Modernities', in which the architect of this nascent theory, the Israeli sociologist, Shmuel Eisenstadt, wrote: 'One of the most important implications of the term "multiple modernities" is that modernity and Westernisation are not identical; Western patterns of modernity are not the only "authentic" modernities.' (Eisenstadt 2000, 3) Advocating a more pluralistic approach to modernity and thereby stripping the West of its monopoly appears simple, but it has been quietly ground-breaking, especially in architecture, architectural historiography and in the field of cultural heritage, despite the built environment disciplines lagging years behind related disciplines.

Eisenstadt's theory is one of several attempts at the construction of a theoretical framework that challenges the master narratives established in the last century that are proving redundant in this century. Theories advocating a more plural approach to the historiography of modernity, whether multiple, alternative, indigenous, colonial, etc, are gaining increasing approbation in architectural studies as more research is done that exposes the architectural experiences of countries beyond the Western gaze. In 2009, for example, Multiple Modernities in Muslim Societies edited by Modjtaba Sadria won the Aga Khan Award for Architecture (Sadria 2009). In 2015, the publication of African Modernism claimed defiantly that 'Europe can no longer claim exclusive rights to modernity' (Herz 2015, 4).

However, there is a still a long way to go and many people would argue the pace of change is too slow. In 2012, the Singaporean architect, William Lim, used the published proceedings of a 2011 conference in Singapore titled Non-West Modernist Past to claim that 'Western mainstream literature on modern architecture and urbanism continues with its Eurocentric universality and dominance. Even significant contributors of the 'non-West' are 


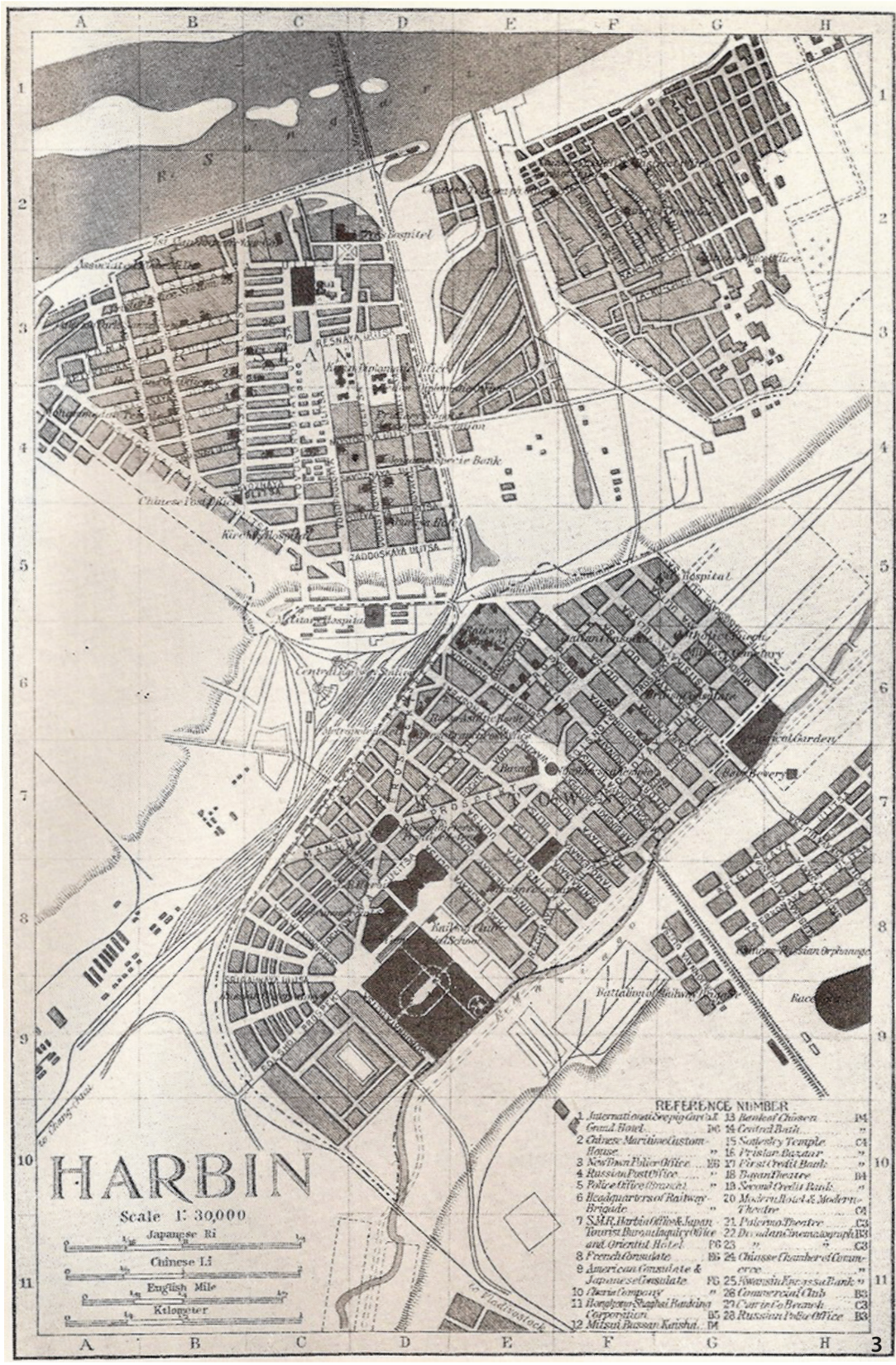

Figure 3 The Russian urban plan for Harbin, a city created at the end of the $19^{\text {th }}$ century by the construction of the Trans-Siberian Railway, 'one of the greatest arteries of traffic the world has ever seen [and] one of the chief factors in shifting the centre of gravity of the world's trade, and today boasting a population over 10 million (Colquhoun 1898, 327-328) (Source: the author). considered peripheral and ignored' (Lim 2012, 2). What is important here, as the voice of former others increasingly gets heard, is the need, as Jyoti Hosagrahar emphasises in Indigenous Modernities, 'not merely to celebrate and give voice to minority discourses and knowledges in order to include them in their subordinate positions in existing privileged accounts of modernity, but to question the master narrative' (Hosagrahar 2005, 6).

It might take a generation before 'other' histories become sufficiently numerous and articulate as to change the master narrative, but there is no question that this is underway and that, consequently, 'studies of the future are likely to take into greater account societies and religions, traditions and practices still too little known today, concealed from the West by many factors' (Graubard 1998, vii). For architecture and modern urban heritage, this is both very exciting and vitally important, since our lack of knowledge and awareness of some of the world's largest and most rapidly changing cities is not only precipitating the damage, destruction and loss of significant buildings and historic urban environments through the absence of proper research and reliable information, but it also impairs our ability to encourage positive urban change through new and creative responses founded on or enabled by informed management, policy-making, new approaches and innovative design interventions. 


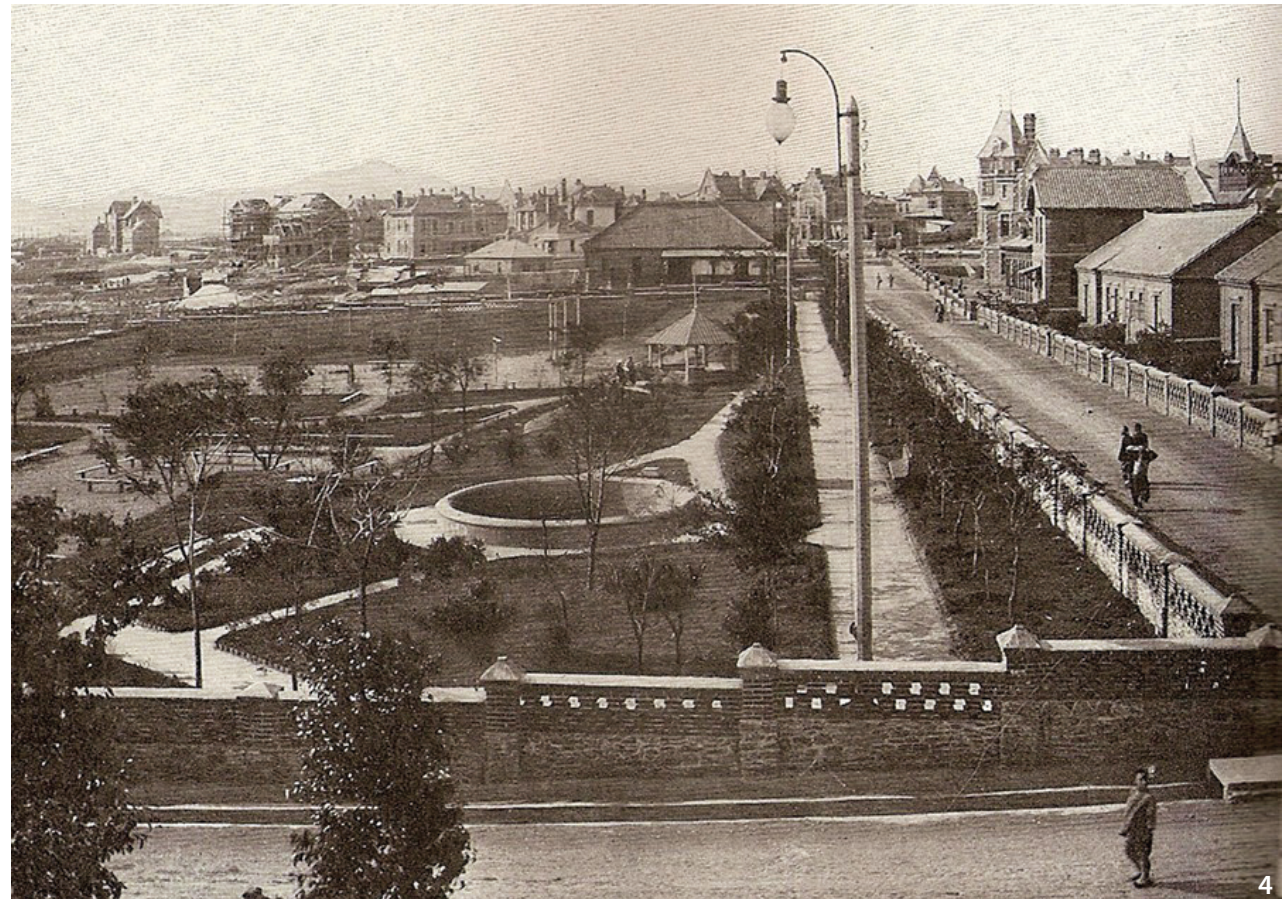

Figure 4 The new Russian port city of Dalny (meaning 'far place' in Russian) on the Chinese coast, described in 1904 as 'A "boom" town without any reason for a "boom"', and a century later a city with a population of over 6 million (H.J.Whigham, Manchuria and Korea, Isbister \& Co., 1904, p.8) (Source: Scribner's Magazine, April 1903).

\section{Modern Heritage and the Modern City}

This paper's focus on modern heritage is not to imply a lack of interest in older heritage, rather it is motivated by two overarching conditions associated with the impending Anthropocenic age. The first is that modern heritage has, by its comparative contemporality, enjoyed less attention than older heritage, and secondly that, as a manifestation of modernity, modern heritage is integrally linked to the conditions of the $20^{\text {th }}$ century. To understand the present and prepare for the future, we need to better understand the global experiences of the recent past, which gave rise to the systems, infrastructures, and urban forms that now barely sustain life on earth for our species.

The modern city, born or raised in the $20^{\text {th }}$ century, will play a vital role in heritage research and practice in the $21^{\text {st }}$ century. In little over a hundred years, the modern city has been instrumental in facilitating a near fivefold increase in the total human population from 1.6 billion people in 1900 to 7.6 billion today. The modern city is also largely responsible for the fivefold increase in the human urban population since the end of the Second World War, which has risen from 751 million in 1950 to 4.2 billion in 2018, resulting in the urbanisation of our species around 2007 (United Nations 2018). In China, entirely new cities that were created at the turn of the $20^{\text {th }}$ century, such as Dalian and Harbin, are now home to over six and 10 million people respectively. No significant human settlement existed in either place until the Russians started building the branch line from the Trans-Siberian Railway down to the Chinese coast from 1898. At the ' $\mathrm{T}$ ' junction grew Harbin and at the coastal terminus was established the Russian town of Dalny, meaning 'Far Place' in Russian (Figure 3, Figure 4). The plans for Harbin designed by the Russian engineer Obromievski in 1898 and for Dalian by railway engineer, Mr Kerbech, and the future governor and chief of engineering construction, $\mathrm{Mr}$ Saharoff ${ }^{4}$, were the first modern urban plans to be implemented in China. Such ordered and comprehensive modern planning eluded most of the foreign treaty ports that plagued China's coasts and rivers. In Shanghai, for example, from where the British invaded China in 1842 and prized open China to foreign trade, the persistent short-term thinking of foreign merchants prevented long-term planning. Nevertheless, today the city is one of the largest on the world with a population of over 24 million (Figure 5). The small island that at the same time became a British colony of Hong Kong is now home to over 7 million people. The nearby former treaty port of Canton, now better known as Guangzhou, today has 14.5 million residents, but more remarkable is the new city of Shenzhen that the Chinese built between Guangzhou and Hong Kong. From agricultural land in the 1980s, Shenzhen has grown to become a city of 12.5 million, making it larger than any European or North American city. In less than thirty years Shenzhen has become larger than any city in the West, yet our theories or urbanism, architecture and conservation remain based largely on Western precepts. 


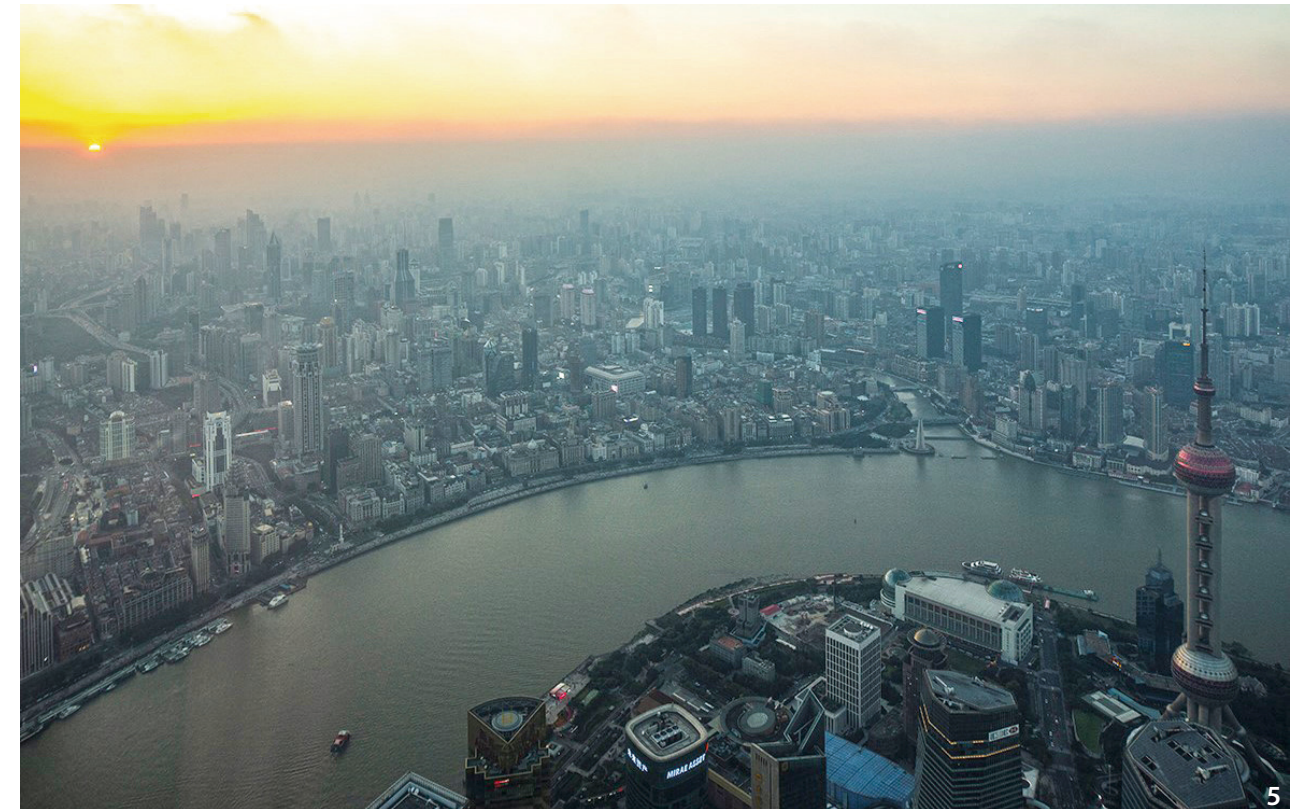

Figure 5 The vast urban landscape of Shanghai, a modern city par excellence and home to nearly 25 million people (Source: the author).
While the growth of Asian cities has been exceptional throughout the latter half of the $20^{\text {th }}$ century, this unprecedented growth might be outstripped by that of African cities in the $21^{\text {st }}$ century. According to research published in the Financial Times newspaper in 2018, the pace of expansion of African cities will exceed by some distance those in other continents over the next two decades (Pilling 2018). The 1.5 million population of the Ugandan capital, Kampala, is expected to grow by nearly $140 \%$ in the next decade and a half. Upon independence in 1962, it was home to just 60,000 people. In neighbouring Kenya, the population of the capital Nairobi has increased tenfold since independence in 1962 to exceed 3 million in 2018 (Figure 6). The capital of Burkina Faso, Ouagadougou, which in 2018 has a population of 2.2 million, is expected to rise by $115 \%$, while Tanzania's coastal city of Dar es Salaam will grow by $120 \%$ from the current 4.4 million. Kinshasa, capital of the Democratic Republic of Congo, already has a resident population of over 10 million, making it the largest French-speaking city in the world. While Asia and Africa continue to transform our perceptions and experiences of the modern city, these $21^{\text {st }}$-century metropolises feature comparatively little in scholarly research, reminding us of Graubard's cautionary comment about studies of the future needing to take into greater account subjects that have been and continue to be concealed from the West.

The modern city is not only substantially larger, more varied and more complex than its predecessors, it is also increasingly the home of a new kind of human culture in which the former attributes that once defined different human groups up until the $20^{\text {th }}$ century, such as birth place, language, religion, nationhood, and customs, become assimilated, reconstituted and reimagined. Often framed as a defining characteristic of globalisation, this phenomenon might take longer to realise than the $21^{\text {st }}$ century, but there can be no doubting or resisting its inevitability. At the start of the $20^{\text {th }}$ century there still existed many human cultures that had no contact with or impact from other humans. By the mid- $20^{\text {th }}$ century, this state of existence, which had lasted since human species started to walk the earth a third of a billion years ago, ceased for ever. Whether the finger of responsibility for heralding a planetary culture should be pointed at invisible radioactive isotopes emitted into the global atmosphere from the testing of nuclear weapons or the cumulative effects of burning fossil fuels, modernity has caught up with every single human being on this planet. Every single person and almost every living thing on this earth is touched by the effects of our species-the very definition of the Anthropocene. As sure as the extinction of isolated human cultures was in the $20^{\text {th }}$ century, so too will be the dawn of a global human culture in the $21^{\text {st }}$ century.

A global human culture is not to be confused with a single homogenous culture. This was the central thesis of $20^{\text {th }}$ century modernisation theory, which 'took for granted that modernisation would lead to "homogenisation"', wherein 'cultural diversity could not possibly survive' (Graubard 2000, x). Just as 'studies of modernisation assumed that the project of modernity would exhibit hegemonic and homogenising tendencies, and that it would not only continue in the West but spread and prevail throughout the world ... The reality proved to be 


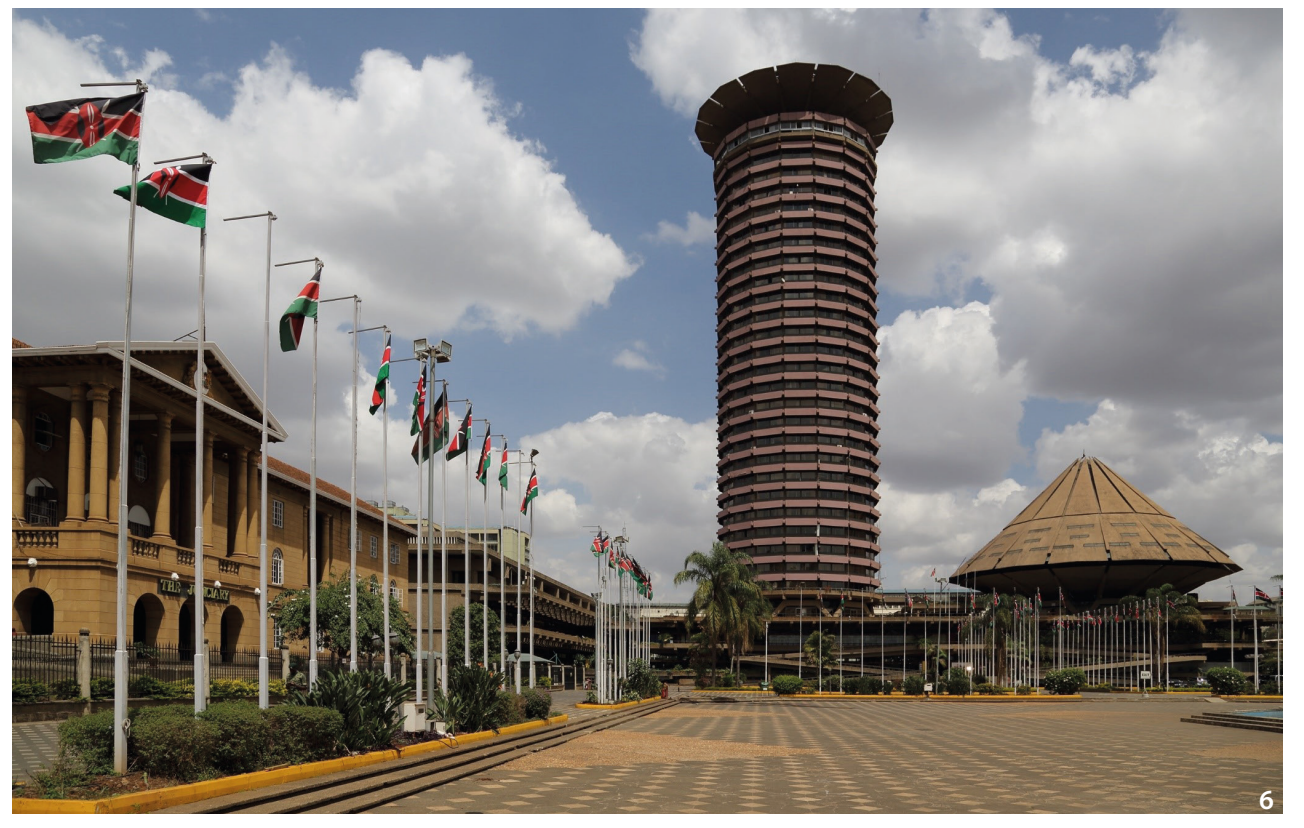

Figure 6 The 105 m-high Kenyatta International Convention Centre in Nairobi (1973), designed by David Mutiso and Karl Henrik Nøstvik, which became a powerful architectural symbol of Kenyan independence in an icon of a burgeoning capital (Source: the author). radically different' (Eisenstadt and Schluchter 1998, 4). As Eisenstadt and Schluchter contend, 'The actual developments did not bear out the assumption of convergence, not even in the West.' (Eisenstadt and Schluchter $1998,4)$ As long as culture is constantly changing, a homogenous human culture is impossible, but it does pose some important questions for cultural heritage and the built environment in the future. As modern cities of the $20^{\text {th }}$ century are being recognised for their outstanding universal value, what will be the cultural value or contribution to humanity of the $21^{\text {st }}$-century city with its tens of millions of residents? Which millennial cities will follow Brasilia, Tel Aviv, Le Havre, Rabat and Asmara onto the World Heritage List and in what ways will such a global list even be relevant in a future of 12 billion human inhabitants?

If urban heritage is to have any relevance in the modern metropolis, it must adapt to the rapidly changing circumstances in which cities and their human populations will exist in the third millennium. The problem for now, as Professor Mike Turner of Bezalel Academy states, is that 'we are using $19^{\text {th }}$-century tools to deal with $21^{\text {st }}$ century problems ${ }^{5}$. The most challenging of these will be achieving sustainable development. 'The real nemesis of the modern economy', argues Yuval Noah Hariri, 'is ecological collapse' (Hariri 2015, 249). Without a functioning planet, matters of cultural or natural heritage or the modern city are entirely irrelevant. The fourth and final part of this essay briefly examines the role that the heritage industry can play in ensuring the survival not only of our species, but also the planet.

\section{The Historic Urban Landscape (HUL) Approach}

Cities are going to be key to humankind's future, whether that is one of success or failure. Not only are more than half our species residing in cities, but more than half of all greenhouse gases are produced by or in cities, with the significant majority of these being produced by buildings and the construction industry. Our ability to survive beyond the $21^{\text {st }}$ century will rest with our cities and therefore our knowledge of them needs to be more comprehensive, equitable and on a planetary scale. According to the United Nations (2018), 'As the world continues to urbanise, sustainable development depends increasingly on the successful management of urban growth ... Sustainable urbanisation is key to successful development.' While the global community struggles to establish universal agreements on mitigating humankind's impact on the planet through initiatives such as the Paris Agreement, the United Nations' Sustainable Development Goals, and UN Habitat's New Urban Agenda, the gaze of the World Heritage Convention remains largely focussed on the past. The conceptual framework of the Convention, as it is currently written, recognises cities not as complex living, thriving, or declining entities, but as collections of individual architectural objects or ensembles, monuments, historic centres or relics. Such an antiquated approach to recognising the complexity, value and character of cities, especially modern cities, hinders our collective ability to marshal the necessary resources to identify problems and implement the solutions that this new anthropocenic epoch 
demands. In short, the world constructed under the modernist mantra in the $20^{\text {th }}$ century and imbued with its inherent binaries and asymmetries (whether cultural, racial, social, gendered, sexual, geographic, theoretical, etc), has given rise to an Anthropocenic age wherein a planetary consciousness remains elusive. Our species' survival will depend on attaining this consciousness, which in turn will mark the advent of a genuine state of post-modernity.

Within the field of urban heritage, the most developed initiative to recognise cities as living, changing and complex entities is the Recommendation on the Historic Urban Landscape (HUL) published in 2011, which is the latest phase of developments within the sector aimed at giving adequate recognition to the complex cultural, social or natural conditions that imbue buildings, monuments and sites with wider meanings. HUL is therefore a response to the prevailing limitations of the World Heritage Convention and to the negative experiences of rapid development that so many cities, especially outside the West, have encountered in recent decades. The HUL approach looks beyond the conventional urban object (e.g. singular building, monument or ensemble) to acknowledge 'an urban area as the result of a historic layering of cultural and natural values and attributes, including the broader urban context and its geographical setting' (UNESCO 2011). This shifts the 'emphasis from architectural monuments towards a broader recognition of the importance of the social, cultural and economic processes in the conservation of urban values'. It also addresses the urgent ecological crisis by seeking to 'better integrate and frame urban heritage conservation strategies within the larger goals of overall sustainable development.' Furthermore, it recognises the complexity of the city in the $21^{\text {st }}$ century, advocating a 'comprehensive and integrated approach for the identification, assessment, conservation and management of historic urban landscapes within an overall sustainable development framework' (UNESCO 2011).

Where there currently exists a lack of guidance and leadership in the heritage industry in response to the challenges presented by the Anthropocene, HUL provides an opportunity and a framework for an integrated approach that is not only compatible with the UN's Sustainable Development Goal No.11 (Sustainable Cities and Communities) and UN Habitat's New Urban Agenda, but which is also actively in partnership with them. UNESCO's World Heritage Centre recognise this by stating: 'Having one foot on the Sustainable Development Goal, Target 11.4, and the other on the New Urban Agenda (UN-Habitat), the UNESCO Historic Urban Landscape Recommendation, addresses relevant urban issues for historic urban areas. The interlinkages to the Sustainable Development Goals, the New Urban Agenda (UN-Habitat) and the UNESCO's Culture Conventions are critical.' (UNESCO 2018c) However, HUL's dormancy since 2011 and the subsequent failure to ratify and implement the HUL Recommendation are evidence of the challenges faced by those seeking change. All the while our cities continue to grow unsustainably, heritage is placed under impossible pressure or lost, and we add exponentially to the underlying ecological crisis.

A more integrated and holistic approach to cities and to heritage studies more broadly is needed if the planetary challenges of the new millennium are to be met successfully, a scenario that resonates with both the theory of multiple modernities and the HUL approach. Just as the current experiences of modernity, which include climate change, oceanic pollution, and mass migration, pay no heed to national boundaries or cultural identity, the heritage sector must continue to embrace a more equitable planetary outlook and cast off its inherited cultural, disciplinary and professional prejudices. Only then can it make a truly effective contribution to the urban challenges of the $21^{\text {st }}$ century and beyond.

\section{Conclusion}

The impotence of the heritage sector in the face of the planetary scale of $21^{\text {st }}$-century challenges needs urgent attention if we are to successfully intervene in safeguarding existing and future attributes that define the urban heritage of the recent past and of the future. As this overarching survey has attempted to point out, the root of some of these problems extend to the origins of the industry and, much like the modern city, are the product of uniquely $20^{\text {th }}$-century experiences and conditions that have resulted in unintended consequences, the escalation of which now requires urgent attention. For the heritage industry and the modern city in particular, the HUL approach offers a new methodology and framework for not only dealing with the city in the new millennium, but also aligning it with other emergent or existing strategies, such as the UN's Sustainable Development Goals and UN Habitat's New Urban Agenda. With the Intergovernmental Panel on Climate Change issuing an urgent warning in October 2018 that there remains just 15 years in which very substantial efforts must be made to keep global temperature rises beneath the less catastrophic level of $1.5^{\circ} \mathrm{C}$, the sense of urgency and need for action could not be more acute. The heritage industry, not famed for its progressive outlook or embrace of rapid and radical change, 
must act fast if it is to have any relevance in the $21^{\text {st }}$ century. For those engaged in the built environment professions in the Anthropocenic Age, the choice is stark: '... they must choose to either continue contributing to the problem or instead to dedicate themselves to finding novel ways of adaptation' (Korody 2014). Is the heritage industry going to continue being part of the problem or instead be part of the solution? Either way, time is running out.

\section{Notes}

1. The exhibition also included the Star Bar in Kyoto, designed by Isaburo Ueno.

2. Quoted by Ken Oshima on 3 November 2018 at 'A World of Architectural History' conference, The Bartlett School of Architecture, UCL.

3. The original version of the 'Tree of Architecture' shown here appeared in the fifth edition in 1905, while a second updated version was produced for the sixth edition in 1921, prepared by Banister Fletcher's son, also named Banister Fletcher, and his wife, who went unacknowledged as a co-author. The two versions are broadly similar, although the latter incorporates the United States of America crowning the tree's canopy and removes the word 'political' from the 'political and social' root.

4. Dairen, South Manchuria Railway Company, 1935: 3.

5. Turner, Mike. "Modernism for the Future", Kaunas conference, September, 2018.

\section{References}

Colquhoun, Archibald Ross. 1898. China in Transformation. London: Harper \& Bros.

Denison, Edward. 2017. "Modernity in Manchuria." The RIBA Journal 124 (12): 45.

Denison, Edward and Guangyu Ren. 2016. Ultra-Modernism. Architecture and Modernity in Manchuria. Hong Kong: Hong Kong University Press.

Eisenstadt, Shmuel. 2000. "Multiple Modernities." Daedalus 129 (1): 1-29.

Eisenstadt, Shmuel, and Schluchter, Wolfgang. 1998. "Introduction: Paths to Early Modernities: A Comparative View." Daedalus 127 (3): 1-18.

Fletcher, Banister. 1905. A History of Architecture on the Comparative Method. 5th ed. London: Batsford.

Foster, Hal, Rosalind Krauss, Yve-Alain Bois, and Benjamin H. D. Buchloh. 2004. Art Since 1900: Modernism, Antimodernism, Postmodernism. Holborn: Thames \& Hudson.
Gamewell, Mary Ninde. 1916. The Gateway to China. New York: FH Revell Co.

Graubard, Stephen. 1998. "Preface to the Issue 'Early Modernities"' Daedalus 127 (3): v-viii.

Graubard, Stephen. 2000. "Preface to the Issue 'Multiple Modernities"' Daedalus 129 (1): v-xii.

Hariri, Yuval Noah. 2015. Homo Deus: A Brief History of Tomorrow. London: Harvill Secker.

Herz, Manuel. 2015. African Modernism. Zurich: Park Books.

Hitchcock, Henry Russell, and Philip Johnson. 1997. The International Style. New York: W. W. Norton \& Company.

Hosagrahar, Jyoti. 2005. Indigenous Modernities: Negotiating Architecture and Urbanism. London: Routledge.

ICOMOS. 1964. "International Charter for the Conservation and Restoration of Monuments and Sites." Accessed 6 December 2018. http://www.icomos.org/charters/ venice_e.pdf

Korody, Nicholas. 2014. "Architecture of the Anthropocene, Part 1.” Archinet, September 29. Accessed 29 November 2018. https://archinect.com/features/article/109656462/ architecture-of-the-anthropocene-part-1

Lim, William. "Resetting the Modernist Past." In Non-West Modernist Past: On Architecture \& Modernities, edited by William Lim and Jiat-Hwee Chang. Singapore: World Scientific Publishing Co., 2012, 2.

Mitter, Partha. 2008. "Decentering Modernism: Art History and Avant-Garde Art from the Periphery." The Art Bulletin 90 (4): 531-548.

Pilling, David. 2018. "African Cities Surge to Top of Global Growth League.” Financial Times, September 11. Accessed 29 November 2018. https://www.ft.com/ content/9d457d54-b272-11e8-8d14-6f049d06439c

Sadria, Modjtaba, ed. 2009. Multiple Modernities in Muslim Societies. Geneva: I.B. Tauris \& Co. Ltd..

UNESCO. 2011. Recommendation on the Historic Urban Landscape. Paris: UNESCO. http://whc.unesco.org/uploads/activities/documents/activity-638-98.pdf

UNESCO. 2018a. "Global Strategy.” Accessed November 29 2018. https://whc.unesco.org/en/globalstrategy/\#efforts

UNESCO. 2018b. "World Heritage." Accessed December 6 2018. http://whc.unesco.org/en/about/

UNESCO. 2018c. "UNESCO Recommendation on the Historic Urban Landscape." Accessed December 112018. http://whc.unesco.org/en/activities/638/

United Nations. 2018. "UN World Urbanization Prospects: the 2018 Revision." Accessed 29 November 2018. https:// population.un.org/wup/ 